NBER WORKING PAPER SERIES

\title{
RECENT TRADE LIBERALIZATION IN THE DEVELOPING WORLD: WHAT IS BEHIND IT, AND WHERE IS IT HEADED?
}

John Whalley

Working Paper No. 3057

NATIONAL BUREAU OF ECONOMIC RESEARCH

1050 Massachusetts Avenue

Cambridge, MA 02138

August 1989

This paper is a revised draft of a paper first presented at a conference on May 22-23, 1989, at Lehigh University, Bethlehem, Pennsylvania. I am grateful to Colleen Hamilton and Leigh MacDonald for research support, and to David Greenaway and Frank Gunter for comments. The paper draws on material collected during the course of a recent Ford Foundation-supported project on Developing Countries and the Global Trading System. This paper is part of NBER's research program in International Studies. Any opinions expressed are those of the author not those of the National Bureau of Economic Research. 
NBER Working Paper \#3057

August 1989

\title{
RECENT TRADE LIBERALIZATION IN THE DEVELOPING WORLD: WHAT IS BEHIND IT, AND WHERE IS IT HEADED?
}

\begin{abstract}
This paper documents recent external sector liberalization in developing countries, evaluates what is behind it, and assesses whether it is likely to persist, accelerate or reverse itself. It draws heavily upon material collected during a recent Ford Foundation-supported research profect on developing countries and the global trading system (see Whalley (1989)) covering eleven developing countries (Argentina, Brazil, China, Costa Rica, India, Kenya, Mexico, Nigeria, The Philippines, Republic of Korea and Tanzania). Many factors underlie these liberalizations. These include rethinking of the basic approach towards trade policy in a number of countries, with less commitment than earlier to import substitution and more interest in outward-oriented development strategies. Conditionality in World Bank and IMF lending programs appears important in Africa, and in some of the Asian and Latin American countries. In some cases, sector-specific liberalization has also been the result of bilateral pressure from the U.S. and the European Community. Recent strong macro performance in the developed world has also generated substantial growth in foreign exchange earnings for developing countries, and facilitated this liberalization. The paper concludes by suggesting that, in the short to medium term, some reciprocal actions by the developed countries in the GATT Uruguay Round would help in keeping domestic political support for these liberalizations alive.
\end{abstract}

John Whalley

Department of Economics

University of Western Ontario

London

CANADA N6A 5C2 
Table of Contents

II RECENT TRADE IIBERALIZATION IN DEVELOPING

COUNTRIES - WHAT IT IS . . . . . . . . . . . . 6

III FACTORS UNDERLYING RECENT DEVELOPING COUNTRY

TRADE LIBERALIZATION . . . . . . . . . . . . . . . . 17

Intellectual Influences . . . . . . . . . . . . . . il

Global Macro Conditions . . . . . . . . . . . . . 20

World Bank/IMF Conditionality and

Developed Country Pressure . . . . . . . . . . 23

IV EOW DOES RECENT EXPERIENCE COMPARE TO PREVIOUS

EPISODES OE TPADE IIBERALIZATION? . . . . . . . . . 28

Brazil . . . . . . . . . . . . . . . . . 29

India . . . . . . . . . . . . . . . . . . 30

Argentina . . . . . . . . . . . . . . . . . 31

Ohile . . . . . . . . . . . . . . . . . 33

Korea . . . . . . . . . . . . . . . . . 34

$V$ WILL THE PRESENT LIBERALIZATION CONTINUE,

OR IVEN ACCETERATE? . . . . . . . . . . . . . . . . 41

Macro Conditions in OECD Countries......... . . 41

Domestic Political Support for iberalization . . . 42

The Lack of 3inding of Liberalization . . . . . . . 44

Iinks to the Multilateral system . . . . . . . . . . 45

VI SUMMARY AND CONCLUDING REMARKS . . . . . . . . . . . . 48

BIBLIOGRAPHY . . . . . . . . . . . . . . . . . . 49 
INTRODUCTION

This paper tries to document the extent and coverage of recent external sector liberalization in developing countries, evaluate what is behind it, and assess whether it is likely to persist, accelerate or reverse itself. As such, it draws heavily upon material collected during a recent Ford Foundation-supported research project on developing countries and the global trading system (see whalley (1989)) covering eleven developing countries (Argentina, Brazil, China, Costa Rica, India, Kenya, Mexico, Nigeria, The Philippines, Republic of Korea, and Tanzania).

What seems to make this liberalization worthy of study is that much of it appears to have gone relatively unnoticed, while at the same time seemingly representing major change. It covers a iarge number of countries, and in them, a wide range of traderestricting instruments. Not only are conventional trade policy measures (tariffs and quotas) included, but exchange rate policies, capital controls, and policies towards inward foreign investment are also undergoing change. Liberalization seems to have got underway in the early to mid-1980s in some countries, and only more recently in others. In some cases it has steadily gained momentum over these years and in others an initial surge of liberalization has been followed by only slow further change. Previous episodes of liberalization in the developing world, most 
notably in Latin America, have not persisted,2, A central issue for these liberalizations is whether they can also endure.

The paper emphasizes that the liberalization pattern is different across broad continental country groups. In Asia, where growth has been underway for some years and each year an ever enlarging number of countries seem to be growing at high rates, the picture is one of sustained and, in many cases, accelerating liberalization. In the Asian NICs and near NICs, including Thailand, Indonesia and Malaysia, the liberalization process seems well underway and reasonably firmly entrenched. What we are now seeing in addition, is initial flirtation with liberalization in lower income countries, such as India, who for many years have been strongly resistant to liberalization.

In Africa the picture seems to be one of a remarkable turnaround in policy direction. Major changes in foreign exchange arrangements have occurred in a large number of countries where, from independence onwards, trade measures had slowly become ever more restrictive through to the mid-1980s. The relative success of recent exchange rate realignments and currency floating has led some countries to also reduce tariffs and lessen the coverage of quotas. Conditionality in IMF and World Bank lending programs has clearly been a major factor

2 See the discussion of previous liberalization attempts in Bhagwati (1978) and Krueger (1978), who summarize the results of individual country studies in a larger nine-country NBER project. See also Little, Scitovsky and scott (1970) and Balassa and Associates (1982). 
underlying policy changes in this region, but this is not the only reason for change.

In Latin and Central America, trade policy, like domestic policy, remains somewhat erratic and lacking in stability. What seems to be underway at present, however, is substantial rethinking on trade strategies in a number of countries, and a willingness to use increased openness of the economy as a way of lending more stability to domestic policy. Mexico is perhaps the clearest example of significant liberalization, but rethinking of approaches is evident in Brazil and Argentina, even if change in these two countries thus far is less dramatic.

Many factors underlie these liberalizations. There is rethinking clearly discernable of the basic approach adopted towards trade policy in a number of countries, with less commitment than earlier to import substitution and more interest in outward-oriented development strategies. Conditionality associated with World Bank and IMF lending programs appears to be important in Africa, and in some of the Asian and Latin American countries. In some cases, sector-specific liberalization has also been the result of bilateral pressure from the U.S. and the European Community. Recent strong macro performance in the developed world has also generated substantial growth in foreign exchange earnings for developing countries, and facilitated this liberalization. Particularly important has been the sustained recovery of the OECD economies from the 1981 recession, and the 
large trade deficit which the United States has run in the mid1980 s.

Will these liberalizations persist, and possibly further accelerate? As with all liberalization, one can find grounds for skepticism at the same time that one sees reasons for optimism. other smaller waves of Iiberalization in the 1960 s and 70 , especially in Latin America, have not lasted. However, this set of recent changes in policy appear to be more extensive and reflect deeper intellectual change than characterized former episodes. The paper concludes by suggesting that, in the short to medium term, some reciprocal actions by the developed countries in the GATT Uruguay Round would help in keeping domestic political support for these liberalizations alive. What happens will also depend on the performance of the $O E C D$ economies in providing continued growth in export earnings for developing countries. 
6

RECENT TRADE LIBERALIZATION IN DEVELOPING COUNTRIES -

WHAT IT IS

Recent trade liberalization in developing countries takes different forms in different countries. Its notable features are its extent by country and its wide-ranging coverage across both financial and real-side trade restrictions.

As is weil known, the trade regime in most developing countries is complex, reaching out well beyond the tariffs that trade theorists conventionally analyze to a wide array of both trade-restricting and trade-promoting measures. Traderestricting measures include quotas (quantitative restrictions), rationed foreign exchange, advance deposit schemes, export taxes, and export bans. Trade-promoting measures can include duty remissions on inputs for re-export, free trade zones, prioritization in credit rationing, registration schemes for importers which require re-export, and other devices. What constitutes ilberalization is not always clear, and measuring its extent is even more difficult. As a result, there has been iftle in the analytical if terature that indicates exactly how one measures the degree of liberalization.

Despite these problems, there seems to be unmistakable evidence that iberalization in the developing world is both underway and extensive. Table 1 summarizes recent liberalization experience in eleven developing countries participating in the Ford Foundation-supported project on developing countries and the global trading system. As a by-product of project activities, 
Table 1

\section{SLMMARY OF RECENT TRADE IIBERALIZATION EXPERIENCE IN \\ 11 DEVELOPING COUNTRIES PARTICIPATING \\ IN A FORD FOLNDATION-SUPPORTED PROJECT ON \\ DEVELOPING COUNTRIES AND THE GLOBAL TRADING SYSTEM 1}

\section{Argentina}

- Liberalization initiated in 1987 .

- Product coverage of quantitative restrictions reduced from 62.3 percent to 36.8 percent of imports.

- September 1988 - coverage of quantitative restrictions further reduced to 18 percent: expected to decline to 15 percent in early 1989.

- Substantial reouction in import licensing.

- In second half of 1988, average tariff reduced to 30 percent and tariff structure rationalized within a range of 5 to 40 percent.

Brazil

Juìy 1988, tariff reform program went into effert.

- Measures included new customs tariff with lowered rates for many items.

- Elimination of tariff exemption program.

- Average nominal import tariff reduced from 51 to 40 percent (although most nominal tariff rates are lowered. the reform is expected to have neutral effect on average tariff).

- Two domestic taxes levied on nost imports abolished.

- Some reduction in non-tariff measures.

\section{China}

- Open-door policy initiated in 1978.

- Four special economic zones established in 1980-81, followed by opening of fourteen coastal cities.

- Island of Hainan opened to trade in 1984.

- Major trade reform package announced in 1987 included more decision-making powe 5 to foreign trade and export-oriented enterprises. reduction or exemption of caxes on exports, redistribution of foreign exchange earnings in favour of enterprises making finished products.

\section{Costa Rica}

- Revised trade policy in 1982 with major emphasis on improving export capacity.

- Foreign exchange market reorganized and stabilized in 1982 and 1983.

- Now appijes Common External Tariff of Central American Common Market.

- Exports promoted through export contract regime of temporary import admission and free export processing zones.

1 See whaliey (1989) where the research papers and other output from this project is described, and where more detall is available. 
India

- Some trade liberalization and export promotion measures initiated in 1985.

- In 1988. India reduced tariffs on 300 agricultural items.

- The auxiliary customs duty was reduced or abolished for many items.

- 50 products liberalized in July.

- Around 750 items were added to the ilst of products eligible for Open General Licensing. which. in effect, allows for quota-free importation if foreign exchange can be obtajned.

\section{Kenya}

- Trade liberaijzation initiated in 1980 as part of a structural adjustment program.

- Reforms inciaded reduction of non-tariff barriers, lowering of import duties and depreciation of Kenyan currency.

- In $i 986$. iluties on a range of imports ei iminated or reduced.

\section{Korea}

- I.jberalization process iaunched in 1978 and accelerated in early 1980 s.

- Three year pian announced in 1988 to exempt al 1 manufactured goods of discretinnary import jicensing aiong with as many agriculturaj products as possibie.

- Between 1989 and 1993. tariffs expected to be reduced annually to an overall average of 8 percent.

- Average tariff on non-agricultural products will be reduced to 6 percent by 1993 , while average on agricultural products will be 17 percent.

\section{Mexico}

- July i985, significant import permit liberalization program jaunched.

- At the time. 3,600 out of 4,400 tariff items controlled by quantitative restrictions were liberalized.

- By end 1987, coverage of quantitative restrictions had been reduced to 24 percent of trade.

- Maximum tariff now reduced to 20 percent ad valorem from 100 percent before 1985.

- Average tariff declined to 10 percent from 23 percent.

- Effective January 1988. Mexico eliminated "official prices" for customs valuation purposes.

\section{Nigeria}

- Major trade liberalization injtiated in 1986 as part of structural adjustment program.

- Previous import licensing system abolished september 1986.

30 percent import levy discontinued.

- Tariff reform resulted in substantial cuts in import duties.

- October 1986 . exchange rate system restructured. Second-tier foreign exchange market established - exchange rate now market-determined.

- 1987. advance payment of import duties reduced from 100 percent to 25 percent 
Nigeria (continued)

- Import of raw materials and intermediate goods for use in manufacturing industry and production of exported goods free of duty or other indirect taxes and charges.

\section{The Philippines}

- Phase I of import iiberalization progran (1981-1987): import controls i iberalized on 2,185 items.

- Temporarily suspended 1984-1985 due to balance-of-payments crisis.

- Phase II of programs covers remaining 637 items stili covered by import controls. I. ist $A$ of 104 items to be 1 iberaized before end 1989 . List $R$ of 453 items to be decided before end 1989 . List $C$ of 114 items to be restricted indefinitely for health. safety and security reasons.

- Under Tariff Reform Program (1981-1985), average tariff lowered from 43 percent to 28 percent.

\section{Tanzania}

- Liberalization undertaken in 1984 when own-funds scheme implemented.

- Mid-!986 Economic Recovery Program launched.

- Measures inciuded significant exchange rate adjustments, adjustment in interest rates, increases in producer prices in real terms for export crops, and a signifirant reduction in the number of price-controlled items.

- Reforms expected to be implemented in 1989 include: reduction in import restrictions and reduction in use of administrative allocation of foreign exchange. rationalization of tariffs and sales taxes, liberalization in internal trade and pricing and improved export incentives.

Sources: Whail ley (ed.) (1989)

UNCTAD (1988) TD/B/1196 
information on recent changes in trade policies has been generated in all the eleven countries involved (Argentina, Brazil, China, Costa Rica, India, Kenya, Mexico, Nigeria, the Philippines, Korea, and Tanzania). The picture which emerges is that in one form or another, trade liberalization appears to be underway in alj of these countries, although at varying speeds and with differing aegrees of commitment.

One particuiarly striking example is Mexico ${ }^{3}$ which has witnessed both major rethinking on trade and development strategies in policy circles in the last few years, and significant liberalization. Its trade liberalization efforts were initiated in mid-1985, and by the end of 1987 the coverage of quantitative restrictions (import licensing and/or official reference prices) had been reduced to 24 percent of trade. During this period, the maximum tariff was reduced to 20 percent from 100 percent, and the average tariff declined to 10 percent from 23 percent.

Korea 4 is another example of a developing country which has liberalized in a major way. Recent liberalization measures include a three-year plan to free all manufactured goods and as many agricultural products as possible from discretionary import licensing. Between 1989 and 1993, tariffs will fall to an overall average level of 8 percent. The average tariff on non-

3 See Bucay and Perez Motta (1987), Bueno and Villarreal (1988) and IMF Survey (1988a). 1988.

4 See Young $(1988)$. See also Financial Times, August 23, 
agricultural products will come down to 6 percent by 1993, while the average on agricultural products will be lowered to 17 percent.

There has also been extensive change in Africa. In Kenya, 5 a major liberalization of import licensing began in 1980 and adjustment of the tariff regime has been underway since 1981 . In 1986, duties on a range of imports were eliminated or reduced. In Nigeria6 an adjustment program has been in operation since 1986, under which import licensing has been abolished and the number of items subject to import bans has been reduced. Bans on food exports have been lifted, and other export bans and most export licensing requirements have been eliminated. A major reform of the exchange rate system was also introduced in 1986 through a second-tier foreign exchange market in which the exchange rate is market-determined. Tanzania 7 has also recently undertaken an adjustment program that involves comparable liberalization elements.

Many other countries in Africa which followed an import substitution strategy upon independence in the early 1960 s have also begun to liberalize in recent years, and some in a major way. 8 It is unfair to claim that these changes reflect only a

5 See Ikiara (1987), also IMF (1987).

6 see oyejide (1987), also IMF (1987).

7 See Lipumba $(1987,1989)$, also IMF (1987).

8 Beyond the three countries included in the Ford Foundation-supported project, there has been extensive Iberalization elsewhere in Africa. This includes Burundi (1986- 
re-evaluation of their import substitution strategles, since in Africa pressures from conditionality through World Bank and IMF lending programs have also been important. But, despite the pressures from conditionality, adopting import-liberalizing and

88): adoption of a flexible exchange rate policy: liberalization of exchange controls; reduction in the number of import items prohibited or under licence; a restructuring of import tariffs to reduce effective protection; Congo (1985-88): gradual liberalization of import and exchange controls; Gabon (1986-88): liberalization of import controls, liberalization of payments arrangements; Gambia (1985-88): reduced use of quantitative import restrictions, liberalized payments arrangements, exchange rate adjustments including a floating rate; Ghana (1983-88): liberalization of payments arrangements, auction market for foreign exchange, freeing of import licensing system; Guinea (1985-88): flexible exchange rate system, liberalization of payments arrangement through freeing of restrictions on current transactions, reduction in use of quantitative import controls; Guinea-Bissau (1983-88): liberalization of the exchange rate system, abolition of import/export monopolies of state enterprises, liberalized payments arrangements; Madagascar (198688): import liberalization, flexible exchange rate system; Mauritania (1985-88): liberalized import and exchange controls through less reliance on quantitative import restrictions and more flexible exchange rate system; Mauritius (1982-86): flexible exchange rate policy after two large devaluations. liberalized import regulations and payments arrangements: Mozambique (1987-88): adjustments in exchange rates to permit a liberalized import and payments regime, reduction of price control coverage; Niger (1983-88): liberalization of international and external marketing arrangements, narrower scope of price controls; Senegal (1980-88): phased elimination of quantitative restrictions on imports, rationalization of tariff structure to reduce effective protection; Sierra Leone (1986-88): introduction of a flexible, market-determined exchange rate system, liberalized trade and payments systems, accelerated privatization of the rice import system; Somalia (1985-88): reduction in foreign trade restrictions, introduction of floating exchange rate system, provision of export incentives; Uganda (1987-88): adjustments of the exchange rate and movement towards a liberalized payments regime, reduced reliance on quantitative restrictions; and Zalre (1983-88): drastic reform of the exchange rate system resulting in a float of the currency. liberalization of the trade regime, lifting of nearly all controls on prices. The information in this footnote has kindly been provided by Ademola Oyejide of the University of Ibadan, a participant in the project mentioned above. 
export-promoting measures are widely seen in policy circles in these countries as central to any new effort to reverse the decline of their economies.

India 9 has also been moving in a liberalization direction. even if change thus far does not compare with Korea, Mexico and Nigeria. Export promotion measures were emphasized first. 10 In 1986, measures were introduced allowing the sale of raw materials at international prices, the utilization of up to 10 percent of foreign exchange earnings for export promotion purposes, and the import of machinery duty free, or at low rates. More recently, the pace of liberalization has accelerated further with a move of a significant number of previously restricted items onto open General Licensing.

China is another country included in the Ford Foundationsupported project which has been liberalizing its trade and external sector policies. Its present open-door policy has been in place since 1978.11 At the time, China had become aware that it needed to attract foreign capital and technology to speed its development. More recent policy changes have continued their earlier approach of relaxing customs restrictions, lowering

9 See Agarwal (1989) and Manor (1987) for further discussion of Indian trade policy.

10 See IMF $(1987)$.

11 See Guo (1987) for more details. See also GATT (1988b). 
customs duties and introducing new measures to facilitate trade. 12

Major trade liberalization has also occurred in the other countries involved in the project: the Philippines, Costa Rica, 13 Argentina, 14 and Brazil. There are clear signs that a re-evaluation of alternative policy approaches towards trade matters is underway in all these countries. In the two latter countries, there are concrete initial movements in the direction of import ilberalization and export promotion, and reflect a reevaluation of trade policy.

In short, in all of the eleven developing countries represented in the project, there are clear and unmistakable signs of recent moves towards ifberalization. These range from the dramatic (Mexico, Nigeria, and Korea) to the significant (Costa Rica, Kenya, Tanzania, China, and the Philippines) to the small but discernible with potentially major re-evaluations of policy underway (Argentina, Brazil and India). The concern everywhere seems to be the same; improving growth performance by making the domestic economy more efficient, and achieving better export performance through a more open trade policy for imports.

12 It was announced recently in March 1989, for instance, that the 14,000 foreign investment enterprises in China would be allowed to use not only renminbi, but also foreign exchange to quote prices, settle accounts and sell their products. People's Daily, February 22, 1989.

13 See Whalley (ed.) (1989).

14 For discussion of previous liberalization attempts in Argentina, see Corbo and de Melo (1987), and Berlinski and schydlowsky (1982). 
The circumstances may differ by country, especially the weight attached to IMF/World Bank conditionality, but the direction of both thinking and implementation of policy appears the same.

This same picture of extensive developing country trade and external sector liberalization can also be seen in other recent policy documents covering similar issues to that addressed here. For instance, the recent world Bank evaluation of experience with adjustment lending (World Bank (1989)) reports on developments in trade policy in 40 countries receiving adjustment lending. Table 2, which reproduces the World Bank's summary of their experience, paints a similar picture to that emerging from the eleven Ford Foundation-supported project countries. 15

Thus, in a range of developing countries it seems clear that either major trade liberalization is underway, or is now being seriously considered. The questions are why has this happened, and will these liberalizations persist?

15 See UNCTAD (1988) which reports that during the payments crisis of 1982, many Latin American countries increased import restrictions, but recentiy have reversed these policies and in some cases trade regimes are more liberal than before the crisis (page 5). See also Laird and Nogues (1988) for discussion of liberalization in heavily indebted countries. 
Table 2

WORLD BANK EVALUATIONS OF RF.CENT

TRADE POLICY DEVELOPMENTS IN 40 COLNTRIES RECEIVING ADJUSTMENT LENDING

Number of Countries Where Reforms Have Been

Area of Reform

Less

Not

Significant Significant Negligible Total Present Present Total

Overail import policya

QRs on noncompetitive

imports

Protective QRs

Tariff Level

Tariff dispersion

Prutection level

Schedule of future

reduction

Protection studies

Overall export policya

Exchange rateb

Export promotionc

Imports for exports

inports for exports

\begin{tabular}{|c|c|c|c|c|c|c|}
\hline 19 & 10 & 11 & 40 & - & - & - \\
\hline 12 & 16 & 12 & 40 & - & - & - \\
\hline 12 & 17 & 11 & 40 & $=$ & - & - \\
\hline 7 & 20 & 13 & 40 & - & - & - \\
\hline 8 & 22 & 10 & 40 & - & -- & - \\
\hline 13 & 26 & 1 & 10 & - & - & - \\
\hline 6 & 29 & 5 & 40 & - & - & - \\
\hline- & - & - & - & 28 & 12 & 40 \\
\hline 15 & 14 & 11 & 10 & - & - & - \\
\hline- & - & - & - & 38 & 2 & 10 \\
\hline - & - & - & - & 33 & 7 & 40 \\
\hline 17 & 15 & 8 & 40 & - & - & - \\
\hline
\end{tabular}

Note: The assessments refer to proposals supported by the Bank. They do not necessarily refer to policy implegentation.

a Judgement on the significance of the overall reform proposals.

$b$ of ten these were not explicit conditions, but constitute understandings.

frequently made under the program.

c includes such schemes as export credits, insurance, guarantees, and insticutional development.

Source: Worid Bank (1989) 
III FACTORS UNDERLYING RECENT DEVELOPING COUNTRY TRADE

\section{LIBERALIZATION}

Many factors lie behind the recent developing country trade and external sector liberalizations described in the previous section.

\section{Intellectual Influences}

In part, this recent liberalization experience reflects new thinking on trade matters in developing countries. The essence of the process is two-fold; a re-evaluation of the merits of import substitution development strategies on the one hand, 16 and a growing appreciation of the importance of maintaining as open a trading system as possible on the other. The latter factor was accentuated in the early to mid-1980s by the concern that developed countries would turn increasingly protectionist towards developing countries and make access for manufactured exports even more difficult.

The need to look again at import substitution strategies can be traced to a variety of influences. One is the perception that import substitution strategies have not worked as well as was hoped in the $1950 \mathrm{~s}$ and $60 \mathrm{~s}$. Rather than promoting growth, they

16 A recent GATT document notes, for instance, that "Brazil has reportedly abandoned its traditional industrial development policy of import substitution and switched emphasis to a strategy of 'competitive integration' with the world economy." GATT (1988b) Doc. L/6366, p.123. The Philippine tariff reform program of 1981-85 also reflects a conscious effort to move towards a more export-oriented industrialization strategy and away from the import substitution strategy of the late 1950 s to the 1970 s. See Philippine Tariff Commission (1988), Internal document. 
are now seen in some countries as having spawned domestic inefficiency and created a bureaucracy to administer import controls. Importantly, such policles are also seen as inhibiting export performance. 17,18

The allegedly stronger performance of those developing countries which have been more outward-oriented in their trade strategies has been central to the debate on these matters. The performance of the Asian NICs, and particularly Korea, has frequently been held up as a prime example of how import substitution trade strategies have failed, while outwardorlented trade strategies have succeeded. 19

During the period that Korea dramatically increased its growth rate (from the early 1960 s through to the late 1970s), it maintained most of its existing protection, using import duty remissions for export industries instead. It was major export promotion programs which moved the economy towards trade

17 Much of the criticism of import substitution strategles in Latin America, and especially in Brazil, seems to be directed as much at impairment of export performance through higher input costs and lower quality as it is at broader developmental concerns.

18 According to the World Bank (1983) for instance, the Kenyan Fourth Development Plan (1979-83) recognized that "the process of industrialization through import substitution had inhlbited the growth of exports and agriculture". page 95.

19 Influential studies supporting an outward-oriented approach to development include Krueger (1978), Bhagwat1 (1978, $1988)$, and Balassa $(1978,1982)$. See also World Bank (1987) and UN (1985). 
neutrality and substantially changed Korea's trade dependency,20 not conventional trade liberalization. Only subsequently did reductions in tariffs occur. This has led to a confused debate over whether Korean experience shows that a freer trade poiicy stimulates growth.

While abandonment of import substitution is an oversimplification of what happened in the early period of high korean growth, the statement that growth in exports was crucial to korean growth seems incontrovertible, even though free trade was not the chosen route in the early years. A pattern of high export growth following a move from trade repressing import substitution towards a more neutral system of incentives also occurred in other developing countries in the 1960s, including countries such as Brazil. Many of these countries, however, subsequently reverted to a more traditional import substitution approach.

Thus, the issue which current trade policy debates in developing countries are wrestling with is whether import substitution helps domestic manufacturing industries grow so they can later become important in world markets, or whether it simply generates inefficient protected domestic industries and the economy is ultimately prevented from obtaining the benefits of access to more efficient foreign products. The comparison between high-growth economies in Asia on the one hand, and low-

20 See Young (1987), Westphal and Kim (1982), Lee and Naya (1988) and Luedde-Neurath (1986) for more details of the Korean experience. 
growth economies in Africa and Latin America on the other, has been part of this debate. 21

The view that import substitution strategies have not worked well is especially strong in those countries which have made high export growth and economic diversification a top policy priority. In these, achieving efficient domestic production, as opposed to reducing imports, is becoming the new goal of industrial policy. 22 Increasingly, the view is heard that the solution to their development problems lies in more trade involvement rather than iess. 23 This represents a fundamental change in the stance of policy toward both trade and industrialization in a significant part of the developing world, compared to the views which prevalied previously.

\section{Global Macro Conditions}

A further factor which has been central to recent trade liberalization in developing countries is the performance of the global macro economy in the mid to late 1980 s. Since the

21 See whalley (1987) for data on recent growth rates of countries covered by the Ford Foundation-supported project.

22 GATT (1988a), page 7 , reports that "momentum in world merchandise trade accelerated in 1987 because of the sharp turnaround in the import demand of the developing areas". Import volume increased 3 percent in 1987 after a substantial reduction in 1986 .

23 GATT (1988a) page 7 , notes that in developing countries with increases over 10 percent in the volume of merchandise exports in 1987, they also recorded high import volume increases, lending support to the notion that dynamic exporters are dynamic importers. 
recession of 1981 , the worst since the 1930s, there has been strong growth in the ceveioped woz:d; is some years averaging 4 percent in real terms across a: oEOS countries. 24 . It is weli known that trade growth is typica:ly considerabiy higher than income growth, Over the post-war years, global taade has grown at around 4 percent per year, whereas real income growti has averaged approximate:y i percent per year in per capita terms. 2 OECD G:P growth, therefore, has itself fueled growth ir the expont earnings of deveioping countries26 and particulariy in those of the Asian NICS. Dormbusch (:386), suggests that an extra point of GD? growth in the developed countwies contributes about 2 to 3 percert to the export revenise srowth of non-oil developing countinies. In the case of Korea, Taiwan and other vids, expont earnings have increased by iange orders of magnitude in the Gecace of tine : $980 \mathrm{~s}$.

The Inks between Giobal macro conditions and trade iberazizatior in deveiopirg countries arise iargeiy because of the payments regine which most developing cointries typicaily pursue. This is one of fixed or controilea exchange rates aiong

24 OECD countries recorded the foljowing growth rates of reai GNP/GDP: 1983 - 2.9 percent; 1984 - 5.1 percent; 1985 - 3.4 percent: 1986 - 2.7 percent; $: 987-3.4$ percert. See CICD $(: 338)$ page 166 .

25 See Kravis, Jesten and Summers (1932), page $\theta$.

26 In 1987, the feveioping countries sold more than twothirds of their merchandise exports to the developed countries. See GATM (2988a) page 15. 
with other external sector restrictions designed to insulate the economy from external shocks. Developing countries' trade tends to react directly and in a positive direction to any weakening of the foreign exchange constraint which they face. Thus, when export earnings increase as sharply as they have in recent years, imports respond directly as forelgn exchange avallability improves and its rationing becomes looser. 27 In part, the liberalization which we are now seeing, particularly that part of it which is evident in changed exchange rate and payments arrangements, is a reaction to the weakening of the foreign exchange constraint which developing countries have placed themselves under through their choice of payments regime. Should these global macro conditions deteriorate, then an unwinding of the recent liberalization could occur as foreign exchange rationing tightens.

The role of these macro factors in facilitating trade liberalization in developing countries has been reinforced by other factors in the global economy of the 1980s. The behaviour of the U.S. trade deficit has been especially important.28 Beginning in 1984, the U.S. trade deficit moved from relatively small orders of magnitude to deficits in the region of $\$ 150$

27 This is the old notion of "automatic reciprocity" ; the idea that any increases of export earnings by developing countries are automatically reciprocated in the form of increased imports from developed countries. See Prebisch (1964) and Johnson (1967).

28 In 1987 , the U.S. current account deficit reached $\$ 161$ billion. GATT (1988a) page 20 . 
billion a year where it stayed for a number of years before recently starting to fall. Much of the recent growth in export earnings by developing countries is accounted for specifically by increased penetration of U.S. markets. Sampson (1986) reports, for instance, that 80 percent of the growth in export earnings of developing countries in the early 1980 s was attributable solely to increased exports to the U.S. If U.S. fiscal and monetary policies change and the trade deficit falls, it will inevitably have serious implications for developing countries and their liberalization efforts.29 Reversal of the U.S. trade deficit through changed macro policies could, therefore, substantially weaken the impetus to further liberalization in the developing world.

World Bank/IMF Conditionality and Developed Country Pressure

A further factor underlying recent liberalization in developing countries has been the pressure to which some of them have been subjected to liberalize through conditionality in the lending programs of the World Bank and the IMF. 30 These pressures have been compounded by the new aggressive trade policy stance taken by some of the larger developed countries towards developing countries, and particularly the United states, through

29 Dornbusch (1986) argued that in the short term, developing countries would benefit from "the most reckless spending and money printing imaginable".

30 See the discussion of conditionality in Helleiner (1986) and Williamson (1983). 
bilateral threats of GSP graduation and other actions unless liberalization occurs. The latter component of trade policy has been applied most strongly to the Aslan NICs and Brazil, countries which have higher income per capita than other developing countries, and often more liberal trade policies. Threats of unilateral developed country actions applied specifically against individual countries, such as GSP gradiation, 201 and 301 actions have been used with some success to cajole countries into more liberalization. Some of this pressure has been product-specific (such as beef and tobacco in the case of Korea), while other pressure has been targeted to non-traditionai trade areas such as intellectual property matters.31

There is little doubt that bilateral pressure has had some effect on developing country trade policies. But it seems quite small compared to the broad sweep of trade liberalization described above. It is also localized to a small number of highincome growing economies who have significant trade in manufactures and, therefore, can be threatened in this way.

31 The 1985 Korean ban on beef imports resulted in severe bilateral pressure from the U.S. to liberalize. In July 1988 , Korea announced the ban would be replaced by a 14,000 tonne import quota (UNCTAD (1988) page 5). In 1988, the U.S. threatened to graduate Singapore from its GSP scheme if singapore did not take steps to stop infringing on U.S. copyright and trademarks. After taking the necessary measures, the U.S. graduated singapore anyway. In August 1987, Taiwan "gave in to long-standing U.S. pressure to reduce its 4 percent import tax, disguised as a harbour duty fee. It was reduced to 0.75 percent." EIU Country Report Taiwan, 4, 1987, page 14. 
A larger and more pervasive influence has been World Bank and IMF conditionality. Bank/Fund conditionality reflects lending by these agencies which requires countries to make changes in a number of policy areas, including in the external sector. According to the IMF (1988b, pages 32-33), reduction of quantitative restrictions (QRs) was the most common type of specific trade liberalization measure included in Fund programs in the last three years. QRs were required to be reduced in approximately 25 percent of countries granted stand-by or extended arrangements in 1985, and about 50 percent in 1986-87. Tariff reform has also featured prominently and is often undertaken in collaboration with World Bank programs and support. Comprehensive tariff reforms are typically implemented according to a phased schedule accompanying a gradual reduction of QRs.

other types of trade liberalization in Fund-supported programs have included liberalization or abolition of importers' licences; rationalization of the exchange rate used for customs valuation; and abolition of import or export monopolies. Typically, trade liberalization measures were not used as performance criteria in lending, but were evaluated in the context of overall reviews of performance. Conditionality seems to have had the most influence in Africa where the external sector problems and the need for adjustment lending has been. largest. 32 The leverage of these agencies over policy has been

32 See the work by Greenaway and Milner (forthcoming) on Madagascar, who emphasize the role of conditionality in recent African trade policy developments. 
significant because of the need for developmental assistance, and the capability of domestic governments to formulate policy has often been weak. 33

It is, however, possible to over-estimate the extent and influence of conditionality on the liberalization process in other countries. In Latin America, the reaction to these lending programs has, on occasion, been to turn down offers of financial assistance from the Bank and Fund and pursue their chosen country policies independently. Equally, in some of the Latin American countries the volume of lending involved has of ten been relatively small compared to total external sector transactions. For instance, in the Mexican case, although it is sometimes claimed that conditionality has been important in shaping recent trade policy initiatives, in practice this does not seem to have been so becalise the lending involved was small compared to reserves and trade flows.

Nonetheless, Bank/Fund conditionality and pressure from developed countries is undoubtedly a factor in shaping the new

33 African countries' share in IMF assistance under the stand-by and extended facilities reached 30 percent in 1979-80 compared to 3 percent for 1970-78. African countries accounted for 53 percent of the total of stand-by and extended arrangements signed in 1979-80 compared to an annual average of 20 percent for 1970-78. However, earlier African experience with highconditionality loans has been mixed. Out of the twenty African stand-by arrangements concluded with the Fund between 1982 and 1984 , six were not totally used before the deadline or cancellation date and two were cancelled. Of the nine African agreements concluded under the extended facility between 1975 and 1983, eight were not totally used at the deadline or cancellation date and one was replaced by a stand-by agreement. of the eight agreements not entirely used, five were cancelled. See Mawakani (1986) pages 107-109. 
trade and payments regimes in the developing world. Its influence in lower income, smaller debtor countries where alternative sources of funding are not easily available and developmental assistance is needed (as in Africa), is especially large.

There are, therefore, a range of influences which have been important in determining the coverage and speed of recent developing country trade liberalization. There include inteilectual factors which challenge traditional import substitution approacines to development and, in part, reflect the aging of a policymaking bureaucracy raised in the 1950 s and 60 s and its slow replacement by more neoclassicist-inclined technocrats who entered government in the 1970s. There is also the desire to improve economic performance through enhanced export competitiveness. There are the macro factors including sustained OECD growth in the 1980s, and the stimulative effect of the U:S. trade deficit on developing country export earnings. And there are pressures from conditionality in Bank and Fund lending programs and threatened bilateral trade actions by developed countries if liberalization does not occur.

All of these need to be factored in to understand why these liberalizations are now occurring in so many countries, and in assessing where they may be headed in the future. 


\section{TRADE LIBERALIZATION?}

In trying to assess where this liberalization may go next; whether it will persist, accelerate, or dissipate its momentum: it is helpful to compare what is going on at present in the developing worid to previous liberalization episodes. These have been largely concentrated in Asia ardd Latin America, but because they have produced sharply different experiences they are worth studying in some detail.

In the Latin American case, in countries such as Brazil, Chile and Argentina, initial and rapid liberalization experiments in the 1960 s and 70 s proved to be unsustainable in the longer run. The hoped for supply response on the export side never materialized, balance-of-payments problems intensified, and eventually the liberalizations collapsed. In contrast, in the Asian NICs and near NICs (Korea, Taiwan, Thailand, Indonesia and others), trade liberalization has been much more incremental. Initial steps were small and less dramatic than in Latin America. Balance-of-payments problems have arisen, but these have not reversed the liberalization, which has been sustalned in the longer rin. The experience of other countries; such as India, has instead involved single unsuccessful liberalization attempts ( 1966 in India's case) which have undermined support for any repeat attempt. A sense of some of these different country experiences can be obtained from the sequence of events in a few countries. 


\section{$\underline{\operatorname{Brazi} i 1^{34}}$}

The government which took over in the April 1964 coup began a trade liberalization episode in Brazil which lasted until 1973. For the first time in three decades, Brazil moved away from a development strategy based on import substitution. Exports were encouraged by a more flexible exchange rate policy, as well as by the elimination of taxes, licensing procedures and other restrictions. In addition, fiscal reform allowed for the introduction of tax rebates and duty drawbacks which did not exist previously.

Specific export credit facilities to finance production and sales were introduced, as well as specific export promotion programs such as BEFIEX. Under the BEFIEX Agreements in the early 1970s, a large number of firms (particularly in the automobile sector) undertook long-term export commitments (for 10-year periods) in exchange for a package of incentives which inciuded duty-free imports of machinery and inputs, income and value-added tax exemptions and other fiscal subsidies. Also during this period, there was some import liberalization. Tariffs were reduced in 1966-67 such that the effective rate of protection for the industry as a whole was reduced from 108 percent to 63 percent.

The oil price increases of 1973 and the resulting deterioration of the Brazilian terms of trade eventually led to a

34 This section draws heavily on World Bank (1983). See also Abreu and Fritsch (1987). 
return to import substitution policies during the late 1970 , although with a continued emphasis on expanding manufactured exports. The severity of import restriction then intensified further with the debt problems of the early 1980s.

\section{India 35}

India followed an import substitution development strategy in both the immediate post-independence period, and in the period 1956-6i. This was strengthened by the imposition and consolidation of the quantitative restriction regime to control imports. Despite this, the period 1962-66 was one of "partial and haiting efforts at liberalization". 36

This was because there was some export subsidization to reduce the effects of the overvalued currency. There were also steady efforts to unify import duties as well as attempts to streamline the industrial licensing system. On the 6 th of June, 1966, however, the Indian rupee was devalued by 57.5 percent in what was considered a major liberalization announcement. In addition to the devaluation, the full policy package consisted of :

"i) a substantial elimination of the export incentives on non-traditional exports, a simultaneous imposition of countervailing duties to offset the devaluation on traditional exports where oligopolistic competition from rival suppliers was expected (as on tea) and a signifirant reduction of the high import duties;

35 This section draws heavily on Bhagwati and Srinivasan (1975).

36 See Bhagwati and Srinivasan (1975) page 76 . 
(ii) a significant increase in the availability of aidfinanced imports, accompanied by official declaration and implementation of a policy of liberalized import licensing." 37

There were two major factors behind this devaluation. On the one hand, the exchange rate adjustment fitted in with the government's earlier attempts to reduce the effects of the overvaluation through export subsidies. On the other hand, the Aid Inaia consortium had made major devaluation a precondition for the resumption of $a \dot{a}$.

However, the liberalization did not iast long. Even in 1966 there was subsiaization of major non-traditional exports. By 1968-70 aifferential export subsidies merged at significant levels, the quantitative restriction regime continued as did the principie of automatic protection and industrial ilcensing. The restrictive regime of the past slowly returned.

\section{Argentina 38}

Argentina experienced a major liberalization episode between 1976-81, when it was hoped that such measures would eliminate price distortions and help reorganize the economy. In the past, Argentine economic policy (as in other southern Cone countries) had revolved around an import substitution strategy characterized by "expansionary demand policies combined with fixed or slowly

37 See Bhagwati and Srinivasan (1975) page 84 .

38 See Berlinski and Schydlowsky (1982), the EIU Country Profile Argentina $1988-89$ page 10, Preusse (1988), and Corio and de Melo (1987). 
adjusting exchange rates, price controls and restrictive trade regimes". 39

By the 1970s, Argentina's system of import restrictions consisted of prohibitive tariffs, official customs valuations, 40 advance deposits for imports, and preferential arrangements with the Latin American Free Frade Area (IAFTA). In addition, speciaI import regimes existed for a number of industries.

In April 1976 a trade liberalization program began with the progressive removal of prior deposit requirements and quotas on imports. Exchange rates were consolidated from a multiple-rate system to a dual-rate system, which were subsequently merged in December. Further major liberalization followed in 1978-79 when the prior deposit requirement was eliminated, and a program announced to reduce tariffs to an average 16 percent. Export taxes were to be eliminated by 1986.

In 1980 , there were small devaluations in september and october. However, the overvalued exchange rate, combined with high interest rates, was unsustainable. Severe financial strains led to bank faijures in 1980. In 1981, a change of military presidents coincided with massive capital flight and the collapse of the peso and an eventual return to the protection of old.

39 Corbo and de Melo (1987) page 112.

40 According to Preusse (1988) page 890, about "14 percent of tariffs on imports were calculated on the basis of so-called aforo prices which reflected arbitrary valuations by customs authorities rather than c.i.f. market prices". 


\section{$\underline{\text { Chile }} 41$}

Prior to 1973 Chile had followed an import substitution strategy and was suffering from low rates of growth, a large fiscal deficit, high rates of inflation and severe shortage of foreign exchange. While some liberalization had been attempted in 1956-62 and again in the late 60s, the government had reverted to a restrictive trade regime each time. According to Corbo and de Meio (1987), the effective rate of protection to domestic sales in Chile at this time was 151 percent.

A major liberalization program was undertaken in late 1973 when the multiple exchange rate was repiaced by a three-tier system, and followed by a 300 percent devaluation. Between 1973 and 1974 , quotas were removed and the average tariff was reduced from 105 percent to 69 percent and the maximum tariff from 750 percent to 140 percent. In 1975 a unified exchange rate was introduced, and in 1976, a new tariff structure was proposed with rates of 25 percent for primary, 30 percent for semi-manufactured and 35 percent for manufactured goods. In 1977, devaluation was linked to the consumer price index. Following Chile's withdrawal from the Andean Pact, effective tariffs of 10 to 35 percent were proposed with implementation by mid-1977. A uniform tariff of 10 percent was set in 1979 .

41. This section is based on Corbo and de Melo (1987). Preusse (1988), the EIU Country Profile Chile 1987-88, and UNCTAD (1988) TD/B/1196. 
Subsequently, capital flight and balance-of-payments problems intervened. In June 1982, the fixed exchange rate was abandoned and a three-tier exchange rate system came into operation. In March 1982, the uniform tariff rate was raised to 20 percent and 35 percent in 1984 after pressure from domestic industry for protection. However, unlike that in other Latin American countries the liberalization was able to stabiiize itself and resume its iberalization direction. Tariffs were lowered again to 20 percent in 1985 reflecting the government's intention to follow an open-market poiicy. By 1988, the uniform tariff rates were lowered to 10 percent and a 30 percent surtax on imports of luxury consumer goods abolished. Import licences as such are no longer required in Chile, but all requests for imports require a document issued by the Central Bank. Chile is also liberal in its relative lack of foreign investment restrictions.

\section{Korea 42}

Korea followed an import substitution strategy during the i950s and early 1960s. In 1959, high tariffs were imposed on imports, especially finished consumer goods for wich there were domestic substitutes. Other finished goods and luxury items were also subject to high tariffs. Tariffs were lower on products not produced domesticaliy. Low tariffs were also imposed on

42 This section draws on Westphal and $\mathrm{Kim}$ (1982), Young (1987) and Whatiey (ed.) (1989). 
unfinished goods. Feed grains and non-competitive imports of equipment and raw materials entered duty-free. Several major import substituting industries were exempted from tariffs on imports of machinery and intermediate goods. In order to partially offset the effects of an overvalued won, quantitative import restrictions were used. Quotas were the principie means of controlling imports, with import licences revised semiannuaily.

Liberalization began in 1959, but accelerated in the early 1960s. Export incentives were introduced in 1959, but were substantially increased after the election of the civilian government in 1964. Another significant change in 1964 was the establishment of a uniform exchange rate. Trade controls were gradually relaxed after the 1964 devaluation, and the number of items eligible for unrestricted import increased. In the 1970s, the Korean government launched an aggressive program of promotion of heavy industries as new export sectors. Liberalization was halted, if not reversed, during this process which had resulted in a serious loss of international competitiveness in the manufacturing industry by the late 1970s. This strategy was abandoned and the gradual liberalization of the 60 s resumed. The tariff system was reformed in 1984 (after minor reforms in 1976 and 1978) resulting in the introduction of a five-year program of tariff cuts. Tariffs on industrial products were reauced by about a quarter over the period, while at the same time tariffs 
were made more uniform among different stages of processing. Agricultural products were exempt from these tariff cuts.

Liberaiization of the import licensing system followed in 1978, with further change in 1981. A medium-term program was announced in 1983-84 with the aim of making most industrial products free of quantitative restrictions by 1988 .

A three-year plan was announced in 1988 to exempt all manufactured goods of discretionary import iicensing, along with as many agriculturai products as possible. Between 1989 and 1993, tariffs are expected to be reduced annually to an overall average level of 8 percent. The average tariff on nonagricultural products will be reduced to 6 percent by 1993 , while the average on agricultural products will be 17 percent.

There has also been a policy in place since 1984 of steadily increasing the number of manufacturing and service industries in which foreigners can invest. Foreigners are also being given access to selected service industries such as banking, securities, insurance and transportation. It has been the Korean policy that liberalization would take place gradually, beginning with licensing liberalization, then tariff reduction in the industrial sector, with liberalization of agriculture and the service sectors last. 
This sumary represents sharply differing liberaitzation experiences. It is, however, worth stressing that one major difference between the current round of developing country trade liberalization and these previous episodes is that the current iberalization has a clearer global component to it, and is more strongly driven by changed intellectual views in the developing world on how trade policy and growth interact. It is spread across many countries and its impacts on the relative competitiveness of individual developing countries with each other may help sustain it, as will the depth of intellectual commitment which is involved.

The recent wave of liberalization attempts also refiects clearer elements of concern over iniks to domestic economic performance than in former liberaization episodes, and this may also help limit its reversal. Mexico's 1986 entry into the GATT, and subsequent liberalization has, in part, been motivated by the idea of using increased openness to the international economy as a way of disciplining domestic policies. Similar thinking seems to be present in Nigeria's policy changes.

Also, if one looks at the liberalizations which occurred in the 1960 s and 70s, many of these were localized to particular countries and the experiences were much more varied than in the current episode. In India, for instance, there was great frustration felt at the time of the 1966 devaluation because there was an interruption of aid inflows at the same time (see Agarwal (1989)). The Indian economy had partly redirected itself 
towards manufacturing as a result of the expectation of the effects of the devaluation, but this was short-lived because of limited forelgn exchange availability once aid flows were cut. This, in turn, eventually led to the termination of the liberalization experiment. Liberalization episodes in Argentina in 1976, and Brazil in the 1970s, had similar end results, but the triggers which caused the end of liberalization were different.

Current liberaization in Asla, and especially in the Asian NICs (inciuding Korea and Talwan and now Thailand and Indonesia), appears to be moze persistent than in other regions and in some countries invoives a sequentlal liberalization process 43 which spans twenty years or more. In the Korean case, Korea initially liberalized by adopting export promotion strategies, not only through duty remissions schemes, but also with priority allocation of rationed credit and licensing arrangements. This generated substantial growth in export earnings which, in turn,

43 The issue of the timing and sequence of steps in the liberalization process is complex and has been the subject of considerable debate. In a study of industrial and trade policies in six developing countries, Little, scitovsky and scott (1970) also drew attention to the drawbacks of maintaining a highly protected import substitution-based trade regime too long, and advocated a gradual transition to a more liberalized regime. In their view, the transition should begin with the removal of quotas and a devaluation of the exchange rate. Accompanying this devaluation should be an adjustment of tariffs, export subsidies and taxes such that internal prices are unchanged. Gradually, as the transition proceeds, tariffs and export taxes would be reduced. For more detailed discussion, see Little, scitovsky and scott (1970) Chapter 10. For further discussion of timing and sequencing of liberalization, see Edwards (1984) and Wolf (1986). For discussion of African countries' experlences with exchange rate liberalization in the 1980s, see Harvey (1988). 
allowed further acceleration of the liberalization process. The initial step in the korean case was a move towards trade neutrality via export promotion, rather than conventional trade liberalization, per se. As has been suggested above, this sustained liberalization in Asia now appears to be spreading to other countries, and in the Asian case, seems to be both accelerating and broadening.

In the African case, the experience seems to be that, following independence, trade performance progressively deteriorated 44 and was accompanied by trade and financial restrictions of increasing severity in many countries. There were no serious attempts to liberalize as had occurred in Asia, Latin America, and the Indian subcontinent. The African experience thus has relatively few precedents with which to compare it. As a result, the recent turnaround seems sharper and more vigorous compared to liberalization elsewhere, and if comparisons to earlier Latin American experience are at all suggestive, potentially fragile in the longer term.

In summary then, this current liberalization is broadly spread across a large number of developing countries. Comparisons to previous episodes of liberalization are limited primarily to Latin America and the Indian subcontinent, since eurrent liberalization in Asia is largely an acceleration and broadening of previous efforts, and a relatively new experience

44 see the discussion of the Ghanaian case, for instance, in Leith (1974). 
in Africa. What seems to be different this time around, especially in Latin America, is the extent to which there is a willingness to re-examine the Intellectual basis for policy reform, and to question previous deeply held commitments to import substitution development strategles. 


\section{WILL THE PRESENT LIBERALIZATION CONTINUE, OR EVEN}

\section{ACCELERATE?}

Just because current trade liberalization in developing countries seems broader and more firmly intellectually based than earlier episodes, it does not necessarily mean that this liberalization is permanent. In many countries the domestic poitical support for liberalization is weak, and other elements of fragility are only too apparent.

\section{Macro Conditions in OECD Countries}

One reason why these liberalizations in developing countries may prove fragile is the macro situation in the OECD countries. The recovery of the OECD countries from the 1981 recession and the growth of export earnings of developing countries this has generated have been central in facilitating developing country trade iiberalization. A reversal of this growth in export earnings through a combination of slowing OECD growth, a possible recession, and a reversal of the U.S. trade deficit, could sufficiently tighten foreign exchange constraints in enough developing countries to put pressure on the liberalization. 45

The liberalization programs in place in many developing countries are intended, in part, to generate a flow of resources from import-substituting industries into export industries in these countries. This is crucial in order to generate enough

45 This could, however, be partly offset by lower interest rates taking pressure off debt service costs for heavily indebted countries. 
additional foreign exchange to further speed liberalization through increased imports. If the global economy weakens, it has strong rebound effects on developing country exports, especially for commodities and raw materials, and the liberalizations discussed above would be put in jeopardy.

\section{Domestic Political Support for Liberalization}

The relative lack of domestic political support for liberalization in developing countries is also a major impediment to any acceleration of liberalization, and may even be enough to throw it into reverse. Popular support for trade liberalization is usualiy weak and diffuse. Domestic support relies crucially upon the supply response which liberalization is supposed to generate. If the supply response is not there, if export earnings do not increase, if growth rates are not higher than before, and unemployment rates begin to fall, then little can be shown to substantlate the claimed benefits for liberalization which was their motivation in the first place. Weak political support, therefore, makes either acceleration or continuation of liberalization difficult.

It is becoming clear in a number of the developing countries in which liberalization has been initlated in the last few years, that it is now running into precisely these roadblocks (the Philippines, for instance, is a good example).46 Little can be

46 Nigeria is also a case in point. It was felt in Nigeria that by demonstrating its commitment to an "unhindered free market economy", the country's creditworthiness and 
shown in terms of concrete results which substantiate the claims of major improvements in economic performance attributable to the Iiberalization, and hence the liberalization itself becomes weaker and improvements in performance less Iikely.

Also, these liberalizations reflect a combination of external circumstances which both facilitate and propel them. outside pressures through conditionality from the Bank and the Fund are, of course, politically inflammatory and, therefore, one of the threats to the continuation of liberaiization. 47 In many countries liberalization is seen as a tool for developed-countrydominated multilateral agencies to impose their policy views on developing countries, and override national sovereignty and autonomy. Hence, the support for liberalization weakens when it is seen as driven by outside agencies. 48

attractiveness to foreign investors would be restored. This so far has not been the case and there is speculation the government may well decide that the "rewards of economic reform do not justify the political risks". (Africa Confidential Vol. 29, No. i, 1988.) Political support for import liberalization is weakening in the Philippines after imports increased substantially more than exports in 1987. There is also opposition to the IMF-backed economic recovery program in Tanzania .

47 In March 1989, for example, there were riots and protests in Venezuela against an IMF-backed package of policy changes.

48 Shams (1988) notes that adjustment programs would stand a better chance for success if the IMF and World Bank formed coalitions with important interest groups within the countries. 
The Lack of Binding of Liberalization

A further factor which may affect the persistence or otherwise of recent developing country liberalization is that little or none of it is bound in a contractual sense in the GATT. In some cases, it is linked to conditionality in Bank and Fund lending for specific periods of time (typically three to five years). But when the lending program terminates, there is nothing which prevents a reversion to the original policy regime. This has already happened in a number of cases.

The extent to which recent trade liberalfzation is further reversed may thus, in part, be directly linked to the participation of developing countries in global negotiations, and especialiy the GATT Uruguay Round. If, for instance, developed countries take significant initiatives towards developing countries, and developing countries are prepared to bind their recent liberalization in the GATT in return for concessions from developed countries, it makes the reversibility of this liberalfzation less likely. Replacement of instruments abolished by other policy instruments with similar effect is, however, always a possibility.

A related 1ssue is whether, and if so how, the external sector is viewed by policymakers in developing countries as a vehicle through which disciplines can be applied to domestic policies, and cement perceived gains from increased stability in the domestic policy regime. If external sector arrangements are used, in part, to provide for more stability of the domestic 
policy regime through increased openness, then a willingness by developing countries to go further and make liberalization more secure through international bindings may, in the long run, prove to be one of its main guarantors of non-reversibility.

\section{Links to the Multilateral system}

This, in turn, raises the question of wider linkage between these developing country liberalizations and the multilateral trading system. As has been argued in the report from the ford Foundation-supported project mentioned above (see Whalley (1989)), recent developing country actions both on the unilateral liberalization front and through their more active participation in the multilateral framework of the Uruguay Round reflect similar concerns. In the latter forum, they have submitted many proposals and participated in coalitions. 49

On the one hand, unilateral liberalization reflects concerns over weak economic performance and attempts to improve economic performance through increased openness. On the other hand, heightened participation in multilateral fora reflects increased outward-orientation in developmental thinking, and a recognition that a closing of international markets can thwart development. Thus, guarantees of openness of export markets have become central to many developing country trade strategies, even to the extent that these are to be pursued through an opening on the import side.

49 See also Hamilton and Whalley (1988). 
All of these changes have been central in bringing developing countries more centrally into the Uruguay Round negotiations compared to the earlier Kennedy and Tokyo Round negotiations. This, in turn, has moved developing countries part way towards satisfying one of the central developed country demands within the trading system; namely, their demand for fuller participation by developing countries. 50

The Ford Foundation-supported project report argues that the deveioping countries have made two important steps since the launch of the Uruguay Round in 1986: (i) extensive unilateral liberalization as documented and discussed in this paper, and (ii) more active participation in GATT negotiations through proposais and participation in meetings in working groups. Their argument is that if the developed countrles have always wanted fulier participation, they should now move to reinforce this by offers which, in turn, will draw counter-offers on bindings and liberalization from developing countries.

If this is the outcome, and even accelerates into the 1990s, one could begin to initially see the higher income developing countries in Asla, with perhaps one or two more countries in Latin and Central America, coming into a system of international disciplines which constrain their domestic policy actions, and doing so because of the perceived benefits which they see in participating in them. These could then be followed by a series

50 see the discussion in Whalley (ed.)(1989). 
of middle-income countries into the middle 1990s, and eventually a wider range of developing countries.

In the longer term, this would represent a scenario under which the present liberalization solidifies its base and accelerates. The difficulty with this is that both what happens in the intermediate term, and what is done to consolidate these Liberalizations and prevent their reversal in the short run, matter. 51

51 See also Laird and Nogues (1988) for discussion of what ceveloped countries could do to help solidify these liberalizations. 
VI SUMMARY AND CONCLUDING REMARKS

This paper is about recent trade and external sector liberalization in the developing world. It argues that there are major changes underway on the trade policy front in developing countries. Asian liberalization represents a broadening and acceleration of previous liberalization efforts. In Latin America, domestic policy stability seems to be the key objective. In Africa, there is major turnaround in policy with perhaps the most striking changes of any region. These liberalizations are being pursued unilaterally, and largely independently of the trade negotiations taking place in the GATT Uruguay Round.

These recent liberalizations deserve attention because they represent an important move towards the fuller participation in the trading system that developed countries have been asking of developing countries for many years, and these actions have been taken unilaterally. At the end of the day, developed countries have to ask what they can do to reinforce them. The paper suggests that the form their future macro and trade policies take and their multilateral response in the Uruguay Round will be important determinants of their degree of permanence. 


\section{BIBLIOGRAPHY}

Abreu, M. de Paiva and W. Fritsch (1987). "Obstacles to Brazilian Export Growth and the Coming MTNs". Paper presented to working meeting of Ford Foundation Project in London, Canada.

Africa Confidential. Vol. 29, No. 1, January 8, 1988 .

Agarwal, M. (1989). "The Role of the External Sector in India's Development Strategy: Implications for MTN" in J. Whalley (ed.) Developing Countries and the Global Trading System, Volume 1. Macmillan Press Ltd. (forthcoming).

Balassa, 3. (1978). "Exports and Economic Growth Further Evidence". Journal of Development Economics, Vol. 5, pp. 181-189.

Balassa, 3. and Associates (1982). Development Strategies in Semi-Incustrial Economies. Johns Hopkins University Press, Baltimore.

Berlinski, $J$. and D. Schydlowsky (1982). "Argentina" in Balassa and Associates (1982), Development Strategies in SemiIndustrial Economies. Johns Hopkins University Press, Baitimore, pp.83-122.

Ehagwati, J. (1978). Foreign Trade Regimes and Economic Development: Anatomy and Consequences of Exchange Control Regimes. Ballinger Publishing Company for the National Bureau of Economic Research, Cambridge, Massachusetts.

Bhagwati, J. (1988). "Export-Promoting Trade Strategy: Issues and Evidence". The World Bank Research Observer, Vol. 3, No. $1, \mathrm{pp} .27-57$.

Bhagwati, J. and T. N. Srinivasan (1975). Foreign Trade Regimes and Economic Development: India. National Bureau of Economic Research, Columbia University Press, New York.

Bucay, N. and E. Perez Motta (1987). "Mexico" in J. Whalley (ed.) Dealing With the North. Research Monograph, Centre for the Study of International Economic Relations, University of Western Ontario, London, Canada.

Eueno, G. M. and R. Villarreal (1988). "Trade Negotiations in a Mexican Perspective." Paper presented at a Rockefeller Foundation conference on "The Multilateral Trade Negotiations and the Developing Countries", September 15-16, Washington, D.C. 
Corbo and $\mathrm{J}$. de Melo (1987). "Lessons from the Southern Cone Policy Reforms". World Bank Research Observer, Vol. 2, No.

2 , pp. 111-142.

Diaz-Alejandro, C. (1975). "Trade Policies and Economic Development" in $P$. Kenen (ed.) International Trade and Finance. Cambridge University Press, Cambridge and New York.

Dornbusch, R. (1986). "The Effects of OECD Macroeconomic Poicies on Non-0il Developing Countries. A Review". World Bank, Washington, D.C.

Economist Inteligence Unit (1987). Taiwan Country Report \#4, p. 14 .

Economist Intelligence Unit (1988a). Argentina Country Profile 1988-89, London, p.10.

Economist Intelligence Unit (1988b). Chile Country Profile 198788 .

Edwards, S. (1984). "The Order of Liberalization of the Balance of Payments. Should be Current Account be Opened up First?" World Bank, Washington, D.C.

Financial Times. August 23,1988, p.4.

GATT (1988a). International Trade 87-88, Vol.1. Geneva.

GATT (1988b). Review of Developments in the Trading system. Oct. 1987 - March 1988. Doc. L/6366, Geneva, p.123.

Greenaway, D. and C. Milner (1989). "Industrial Incentives, Domestic Resource Costs and Resource Allocation in Madagascar". Applied Economics, forthcoming.

Guo, C. D. (1987). "China" in J. Whalley (ed.) Dealing With the North. Research Monograph, Centre for the Study of International Economic Relations, University of Western Ontario, London, Canada.

Hamilton, C. and $\mathrm{J}$. Whalley (1988). "Coalitions in the Uruguay Round". Working Paper No. 2751, National Bureau of Economic Research, Camoridge, Massachusetts.

Harvey, C. (1988). "Non-Marginal Price Changes, Conditions for the Success of Floating Exchange Rate Systems in Sub-Saharan Africa". IDS Bulletin, Vol. 19, No. 1, pp.67-74. 
Helleiner, G. K. (ed.) (1986). Africa and the International Monetary Fund. International Monetary Fund, Washington, D.C.

Ikiara, G. (1987). "Kenya" in J. Whalley (ed.) Dealing With the North. Research Monograph, Centre for the Study of International Economic Relations, University of Western Ontario, London, Canada.

International Monetary Fund (1987). Exchange Restrictions and Exchange Arrangements. Annual Report. Washington, D.C.

International Monetary Fund (1988a). IMF Survey. June 27, 1988.

International Monetary Fund (1988b). Issues and Developments in. International Trade Policy. Occasional Paper 63, International Monetary Fund, Washington, D.C.

Johnson, H. G. (2967). Economic Policies Towards Less Developing Countries. The Brookings Institution, Washington, D.C.

Kravis, I. B., A. Hesten and R. Summers (1982). World Product and Income: International Comparisons of Real Gross Product. Johns Hopkins University Press for the World Bank, Washington, D.C.

Krueger, A. O. (1978). Foreign Trade Regimes and Economic Development: Liberalization At tempts and Consequences. Ballinger Publishing $\mathrm{Co}$. for the National Bureau of Economic Research, Cambridge, Massachusetts.

Laird, S. and J. Nogues (1988). "Trade Policies and the Debt Crisis". Unpublished, World Bank, Washington, D.C.

Lee, $C$. and $S$. Naya (1988). "Trade in East Asian Development with Comparative Reference to Southeast Asian Experiences". Economic Development and Cultural Change, Vol. 36 , No. 3 . pp.123-152.

Leith, J. C. (1974). Foreign Trade Regimes and Economic Development: Ghana. Columbia University Press for the National Bureau of Economic Research, New York.

Lipumba, N. (1987). "Tanzania" in J. Whalley (ed.) Dealing With. the North. Research Monograph, Centre for the Study of International Economic Relations, University of Western ontario, iondon, Canada. 
Lipumba, N. (1989). "Domestic Supply Constraints versus Market Access: International Trade and Economic Development in Tanzania" in J. Whalley (ed.) Developing Countries and the Global Trading System, Volume 2. Macmillan Press Itd.

(forthcoming).

Little, I., T. Scitovsky and M. Scott (1970). Industry and Trade in Some Developing Countries. A Comparative Study. Oxford University Press, London, U.K.

Luedde-Neurath, R. (1986). Import Controls and Export-oriented Development: A Reassessment of the $\mathrm{S}$. Korean Case.

Westview Press, Boulder, Colorado.

Manor, J. (1987). "Tried, Then Abandoned: Economic Liberalization in India". IDS Bulletin, Vol. 18, No. 4, pp. $39-44$.

Mawakani, S. (1986). "Fund Conditionality and the Socioeconomic Situation in Africa" in G. K. Helleiner (ed.) Africa and the International Monetary Fund. International Monetary Fund, Washington, D.C., pp.107-109.

OECD (1988). OECD EConomic Outlook. December, Paris, p.166.

Oyejide, T. A. (1987). "Nigeria" in J. Whalley (ed.) Dealing With the North. Research Monograph, Centre for the Study of International zconomic Relations, University of Western Ontario, Iondon, Canada.

People's Daily. February 22, 1989, Beijing, China.

Philippine Tariff Commission (1988). Internal document.

Prebisch, R. (1964). "Towards a New Trade Policy for Development". irroceedings of the United Nations Conference on mrade and Development. Geneva, March 23-June 16, Vol. 2.

Preusse, H. G. (1988). "The Indirect Approach to Trade Liberalization: Dynamic Consideration on LiberalizationCum-Stabilization Policies in Latin America" in World Development, Vol. 16, No. 8, pp.883-897.

Sampson, G. (1986). "Structural Change: Accommodating Imports from Developing Countries". Paper presented at International Economics Study Group Conference on Causes of Changes and the structure of International Trade. Isle of Thorns, sussex, U.X.

Shams, R. (1988). "Adjustment Policy and Interest Groups in Developing Countries". INTERECONOMICS, March/April, Vol. 23, pp. $91-94$. 
UNCTAD (1988): "Protectionism and structural Adjustment". TD/B/1196. Geneva.

United Nations (1985). Economic Bulletin for Asia and the Pacific, Vol. XXXV, No. 2, December 1984. U.N., New York.

Westpha1, I. E. and K. S. Kim (1982). "Korea" in Balassa and Associates Development Strategies in Semi-Industrial Economics. Johns Hopkins University Press, pp.212-279.

Whalley, J. (ed.) (1989). The Uruguay Round and Beyond. The Final Report from the Ford Foundation Supported Project on Developing Countries and the Global Trading system. Macmilian Press Ltd. (forthcoming).

Williamson, J.(1982). The Lending Policies of the Internationai Monetary Fund. Institute for International Economics, Washington, D.C.

Wili iamson, J. (1983). IMF Conditionality. Institute for Internationa? Economics, Washington, D.C.

Wolf, M. (1986). "miming and Sequencing of Trade Liberaiization in Developing Countries". Asian Development Review, Vol.4, No. 2, pp.1-24.

World Bank (1983). "Brazil Industrial Policies and Manufactured Exports". Washington, D.C.

World Bank (1987). World Development Report 1987, Washington, D.C.

World Bank (1989). Adjustment Lending. An Evaluation of Mes Years of Experience. Washington, D.C.

Young, S. (1987). "Korea" in J. Whalley (ed.) Dealing With the North. Research Monograph, Centre for the study of International Economic Relations, University of Western ontario, London, Canada.

Young, S. (1988). "The Republic of Korea and the Uruguay Round of Mulilateral Trade Negotiations". Paper presented for the Rockefeller Foundation conference on the MTN and the Developing Countries held September 15-16, Washington, D.C. 